\title{
The Defining Positive Role of High Cell Temperature on the Performance of a Multicrystalline Solar Photovoltaic Module
}

\author{
Shalini Garg \\ Government Polytechnic College, Jodhpur; \\ Rajasthan, India
}

\author{
Arun J. B. \\ Teachers Training Center, Jodhpur; \\ Rajasthan, India
}

\begin{abstract}
The Photovoltaic technology has shown remarkable development in last few years but still lot of research is required to increase the energy yield and reduce solar electricity cost. Even a small increase in energy yield can lead to improved photovoltaic power plant performance and significant reduction in solar generated electricity cost. Evaluating real time data for determining the plants performance plays significant role as it is the climatic conditions which directly affect the power output and evaluating the climatic conditions that can lead to increase the energy yield can bring revolution in the field of solar photovoltaic. This paper evaluates simultaneous effect and role of irradiance and cell temperature on the dc voltage, dc current and dc power, the key determinant of energy yield based on the real field data set of 5 MW grid connected Solar Photovoltaic power plant of Western Rajasthan. It brings forward for the first time ever that high cell temperature plays defining positive role in increasing the energy yield and consequently improving the plant's performance in contrast to literature and research papers.
\end{abstract}

\section{General Terms}

DC Voltage, DC Current, DC Power, Western Rajasthan, high cell temperature.

\section{Keywords}

Solar Photovoltaic Power Plant Performance; Energy yield; Multicrystalline PV module; Cell temperature; Solar Irradiance.

\section{INTRODUCTION}

The plant performance is directly related to the energy yield, higher the energy yield, higher is the electricity generation and consequently better the plant's performance. The energy yield depends upon the dc power which in turn depends upon the dc voltage and dc current. These technological parameters viz dc voltage, dc current and dc power depend upon two most important climatic factors, the irradiance and the cell temperature. This paper evaluates relative effect and role of irradiance and cell temperature acting simultaneously on the technological parameters and in turn the energy yield as shown in figure 1 .

Literature and research papers $[1,2,3,4,5,6,7,8]$ show that efficiency and dc power output decrease with increase in cell temperature. Even the manufacturers specify negative temperature coefficient for $\mathrm{dc}$ voltage and $\mathrm{dc}$ power and positive temperature coefficient for current, with respect to $25^{\circ} \mathrm{C}$ cell temperature.

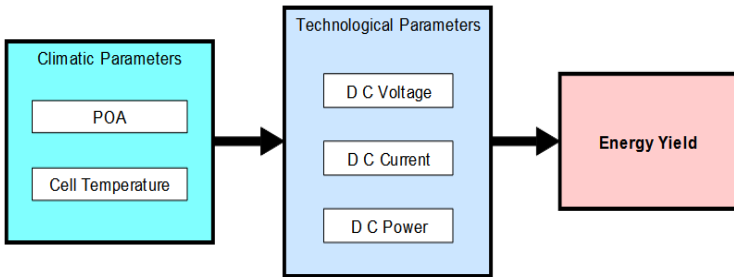

Figure 1- Flow chart depicting the analysis and evaluation procedure.

Few researchers show energy yield in summer is more as compared to winters although efficiency decreases with increase in temperature $[9,10]$. Ciprian et al investigated a grid connected photovoltaic system of Iasi, Romania and found energy yield in summer was far greater than winters [11]. Mazzeo et al. showed that electricity production was more in summers compared to winters and was maximum between 12:00 to 14:00, at the time of maximum irradiance clearly showing production increases with increasing irradiance [12]. Attari et al. showed production in summer was more compared to winters for sites located in north of Morocco [13]. Few researchers showed that irradiance outweighs the negative effect of temperature leading to much higher energy yield in summers as compared to winters [14, $15,16,17]$.

However, Bhattacharya et al. showed positive effect of ambient temperature in $20-38^{\circ} \mathrm{C}$ range on efficiency of a monocrystalline plant installed in Tripura [18]. Touati et. al. showed that Mono-crystalline and Amorphous solar photovoltaic module gives best performance at low humidity and cell temperature around $40^{\circ} \mathrm{C}$ for the climatic conditions of Qatar [19]. Garg, JB showed positive effect of ambient and cell temperature on $\mathrm{dc}$ voltage up to $38^{\circ} \mathrm{C}$ and $50^{\circ} \mathrm{C}$ respectively [20]. In another paper [21] Garg, JB showed significant positive effect of cell temperature in $49^{\circ} \mathrm{C}$ to $62^{\circ} \mathrm{C}$ range and that $\mathrm{V}_{\mathrm{dc}}$ attains nearly constant and high value only at high cell temperature. Garg, JB also showed that significant dc power is obtained only at high cell temperature [22].

However, relative contribution and role of cell temperature and irradiance acting simultaneously on dc voltage, dc current and dc power, the key determinant of energy yield and consequently the plant's performance has not been considered so far. This paper evaluates the relative contribution and role of irradiance and temperature on dc voltage, dc current and dc power for the real field data and brings forward the most vital fact for the first time ever that the cell temperature plays defining positive role in high energy yield in contrast to literature and research papers all which show negative effect 
of cell temperature greater than $25^{\circ} \mathrm{C}$. The plant's performance depends directly upon the dc energy yield and so the performance evaluation of SPV (Solar Photovoltaic) power plant of Western Rajasthan is based dc side energy yield and inverter efficiency has not been considered.

\section{METHODOLOGY}

The analysis is carried out on the data set of a grid connected 5 MW multicrystalline PV power plant located at Ramgarh, district Jaisalmer of Western Rajasthan. The data set is recorded at an interval of 15 minutes interval and is evaluated in the time interval extending from 7:00am in morning to 6:00pm in the evening. The module specifications at STC (Standard Test Conditions) are shown in table 1.

Table 1. The module specifications at STC for the $5 \mathrm{MW}$ grid connected multicrystalline $P V$ power plant located at Ramgarh.

\begin{tabular}{|c|c|c|}
\hline S. No. & Electrical Characteristics & Values \\
\hline 1. & Maximum power $\mathrm{P}_{\operatorname{mpp}} / \mathrm{P}_{\max }$ & $247.39 \mathrm{~W}$ \\
\hline 2. & Voltage at $\mathrm{P}_{\max }, \mathrm{V}_{\mathrm{mpp}}$ & $30.64 \mathrm{~V}$ \\
\hline 3. & Current at $\mathrm{P}_{\max }, \mathrm{I}_{\mathrm{mpp}}$ & $8.07 \mathrm{~A}$ \\
\hline 4. & Open circuit voltage $\mathrm{V}_{\mathrm{oc}}$ & $37.67 \mathrm{~V}$ \\
\hline 5. & Short circuit current $\mathrm{I}_{\mathrm{sc}}$ & $8.26 \mathrm{~A}$ \\
\hline 6. & Temperature coefficient of $\mathrm{P}_{\max }$ & $-0.447 \% /{ }^{\circ} \mathrm{K}$ \\
\hline 7. & Temperature coefficient of $\mathrm{V}_{\mathrm{oc}}$ & $-0.353 \% /{ }^{\circ} \mathrm{K}$ \\
\hline 8. & Temperature coefficient of $\mathrm{I}_{\mathrm{sc}}$ & $0.104 \% /{ }^{\circ} \mathrm{K}$ \\
\hline 9. & Power Tolerance & $-0 /+5 \mathrm{~W}$ \\
\hline 10. & Fuse rating & $15 \mathrm{~A}$ \\
\hline 11. & Maximum System Voltage & $1000 \mathrm{~V}$ \\
\hline
\end{tabular}

2.1 The dc voltage, dc power, POA and cell temperature are plotted with respect to time for specific dates chosen randomly corresponding to different months spread over a year from August 2015 to July 2016. Data for the month of August was not available due to technical reasons.

2.2 The dc voltage, dc current, $\mathrm{dc}$ power and cell temperature are represented by $\mathrm{V}_{\mathrm{dc}}, \mathrm{I}_{\mathrm{dc}}, \mathrm{P}_{\mathrm{dc}}$ and $\mathrm{T}_{\mathrm{c}}$ respectively and their units are $\mathrm{V}, \mathrm{A}, \mathrm{kW}$ and ${ }^{\circ} \mathrm{C}$ respectively. The irradiance used is plane of array irradiance and is represented by POA and is plotted in $\mathrm{W} / \mathrm{m}^{2}$. The $\mathrm{dc}$ voltage, $\mathrm{dc}$ current and $\mathrm{dc}$ power variations in graphs are represented by VDC, IDC and PDC respectively and are followed by respective dates for example VDC-18-10-15 represents dc voltage variations for $18^{\text {th }}$ October 2015.

2.3 The monitored period is divided into four seasons -

i. Post monsoon season extending from September to October

ii. Winter - November to January

iii. Spring - February to March

iv. Summers-April to August
2.4 The time duration for which $\mathrm{V}_{\mathrm{dc}}$ remains constant and the corresponding POA and cell temperature are evaluated for specific dates of different seasons. Let $X_{2}-X_{1}$ indicate the time interval during which $\mathrm{V}_{\mathrm{dc}}$ remains constant. $\mathrm{V}_{1}, \mathrm{~T}_{1}, \mathrm{POA}_{1}$ represent the corresponding values of $\mathrm{V}_{\mathrm{dc}}$, cell temperature and POA respectively at $\mathrm{X}_{1}$. Similarly, $\mathrm{V}_{2}, \mathrm{~T}_{2}, \mathrm{POA}_{2}$ represent the corresponding values of $V_{\mathrm{dc}}$, cell temperature and POA respectively at $\mathrm{X}_{2}$. The average dc voltage, dc power, POA and cell temperature is also evaluated for these dates and is represented by $\mathrm{V}_{\mathrm{av}}, \mathrm{P}_{\mathrm{av}}, \mathrm{POA}_{\mathrm{av}}$ and $\mathrm{T}_{\mathrm{av}}$ respectively.

2.5 The analysis is based on the average reading of five array with maximum rated dc voltage, maximum rated dc current and maximum rated dc power being equal to $735.36 \mathrm{~V}(24 * 30.64), 161.4 \mathrm{~A}(8.07 * 20)$ and $118.687 \mathrm{~kW}$ (735.36*161.4) respectively.

2.6 The effect of dust, wind, humidity and other environmental parameters has not been considered.

2.7 Variation with ambient temperature is not considered as it has been shown [21] that and dc voltage varies in accordance to cell temperature and not ambient temperature.

\section{EXPERIMENTAL DATA ANALYSIS}

To analyse the role of cell temperature on $\mathrm{V}_{\mathrm{dc}}, \mathrm{I}_{\mathrm{dc}}, \mathrm{P}_{\mathrm{dc}}$ and energy yield, the simultaneous effect of cell temperature and irradiance is observed by plotting variation of various parameters viz POA, cell temperature, $\mathrm{V}_{\mathrm{dc}}, \mathrm{I}_{\mathrm{dc}}$ and $\mathrm{P}_{\mathrm{dc}}$ with respect to time.

\subsection{Variation of $V_{d c}$, POA, cell temperature, $I_{d c}$ and $P_{d c}$ with time for post monsoon season}

The variations in $\mathrm{V}_{\mathrm{dc}}$, POA, $\mathrm{P}_{\mathrm{dc}}$ and cell temperature with respect to time for $11^{\text {th }}$ September and $18^{\text {th }}$ October 2015 are shown in figure 2 and 3 respectively. The variations in $I_{d c}$, POA and cell temperature with respect to time for $11^{\text {th }}$ September and $18^{\text {th }}$ October 2015 are shown in figure 4 and 5 respectively. The time duration for which $\mathrm{V}_{\mathrm{dc}}$ is constant is evaluated in table 2 .

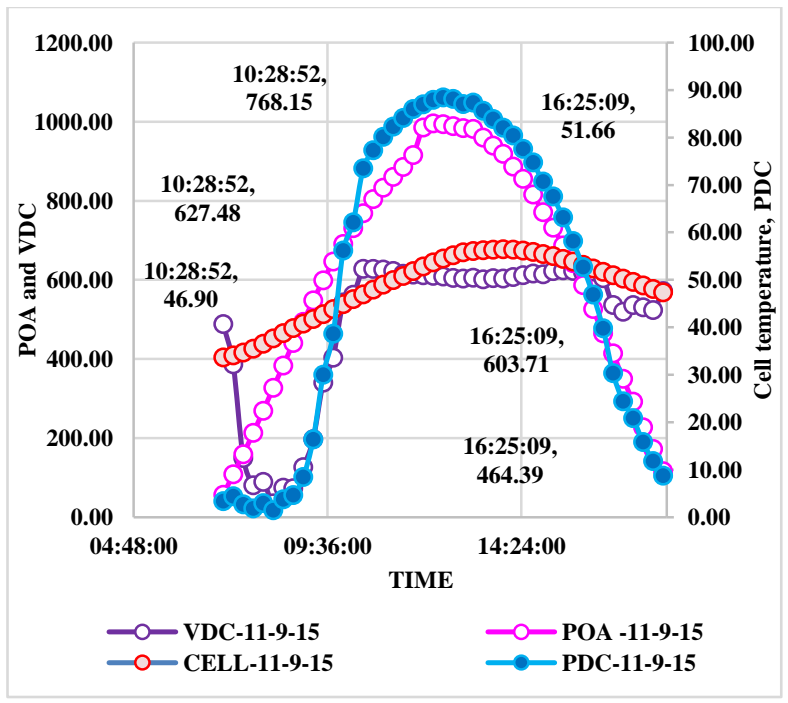

Figure 2 -Variation of $V_{d c}, P O A$, cell temperature and $P_{d c}$ with time for $11^{\text {th }}$ September 2015. 


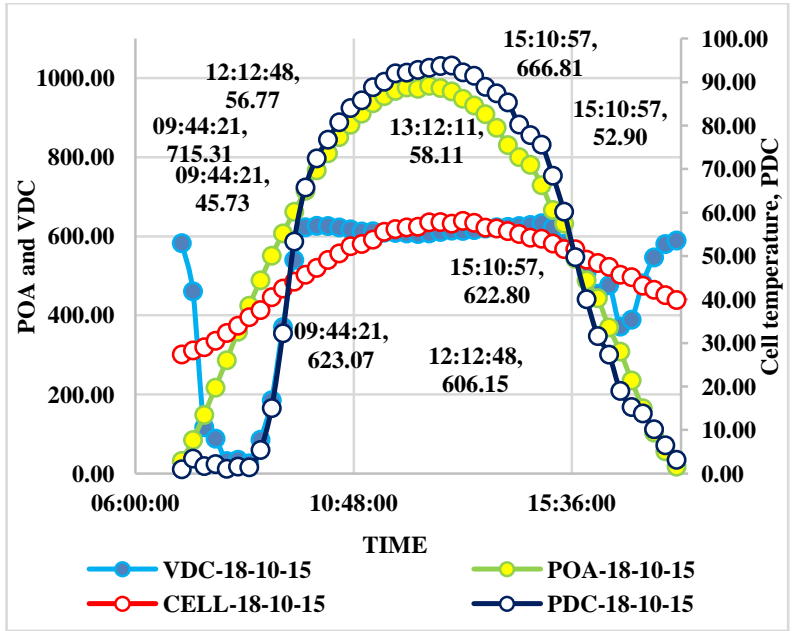

Figure 3- Variation of $V_{d c}, P O A$, cell temperature and $P_{d c}$ with time for $18^{\text {th }}$ October 2015.

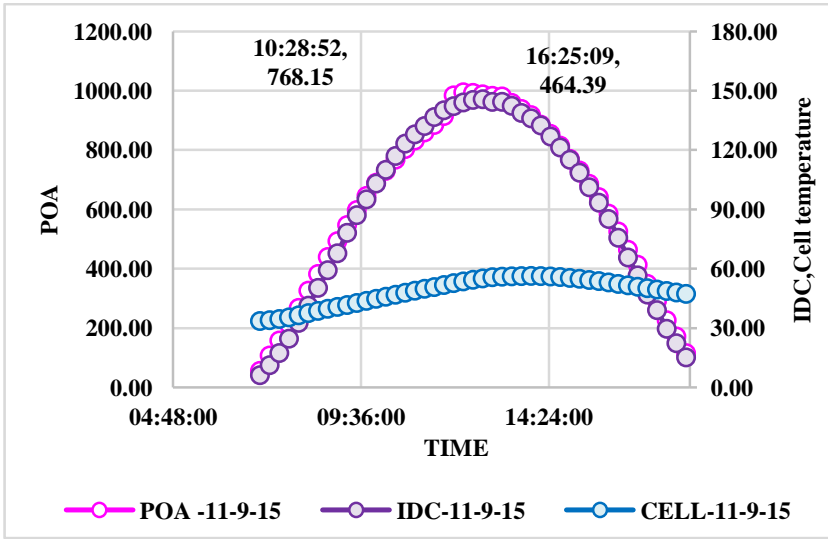

Figure 4- Variation of POA, cell temperature and $I_{d c}$ with time for $11^{\text {th }}$ September 2015.

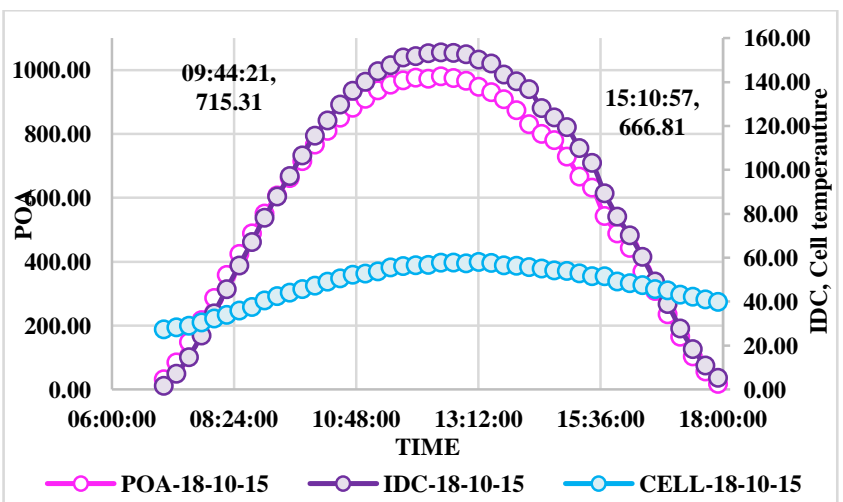

Figure 5- Variation of POA, cell temperature and $I_{d c}$ with time for $18^{\text {th }}$ October 2015.
Table 2- Evaluation of the time duration for which $\mathbf{V}_{\mathrm{dc}}$ remains constant for the post monsoon season

\begin{tabular}{|c|c|c|c|c|c|c|c|c|c|}
\hline $\begin{array}{c}\text { D } \\
\text { at } \\
\text { e }\end{array}$ & $\mathbf{X}_{1}$ & $\begin{array}{l}V_{1} \\
\text { in } \\
V\end{array}$ & $\begin{array}{l}\mathrm{T}_{1} \\
\text { in } \\
{ }^{0} \mathrm{C}\end{array}$ & $\begin{array}{c}\text { PO } \\
\mathbf{A}_{1} \\
\text { in } \\
\text { W/ } \\
\mathbf{m}^{2}\end{array}$ & $\mathbf{X}_{2}$ & $\begin{array}{l}V_{2} \\
\text { in } \\
V\end{array}$ & $\begin{array}{l}\mathrm{T}_{2} \\
\text { in } \\
{ }^{\circ} \mathrm{C}\end{array}$ & $\begin{array}{c}\text { PO } \\
\mathbf{A}_{2} \\
\text { in } \\
\mathrm{W} / \\
\mathbf{m}^{2}\end{array}$ & $\begin{array}{c}\mathbf{X}_{2} \\
- \\
\mathbf{X}_{1}\end{array}$ \\
\hline $\begin{array}{c}11 \\
- \\
9- \\
15\end{array}$ & $\begin{array}{l}10: 2 \\
8: 52\end{array}$ & $\begin{array}{c}62 \\
7.4 \\
8\end{array}$ & $\begin{array}{l}46 \\
.9 \\
0\end{array}$ & $\begin{array}{c}76 \\
8.1 \\
5\end{array}$ & $\begin{array}{l}16: 2 \\
5: 09\end{array}$ & $\begin{array}{c}60 \\
3.7 \\
1\end{array}$ & $\begin{array}{l}51 \\
.6 \\
6\end{array}$ & $\begin{array}{c}46 \\
4.3 \\
9\end{array}$ & $\begin{array}{c}5 \\
\text { hrs } \\
40 \\
\text { min } \\
\text { utes }\end{array}$ \\
\hline $\begin{array}{c}18 \\
- \\
10 \\
- \\
15\end{array}$ & $\begin{array}{c}9: 44 \\
: 21\end{array}$ & $\begin{array}{c}62 \\
3.0 \\
7\end{array}$ & $\begin{array}{l}45 \\
.7 \\
3\end{array}$ & $\begin{array}{c}71 \\
5.3 \\
1\end{array}$ & $\begin{array}{l}15: 1 \\
0: 57\end{array}$ & $\begin{array}{c}62 \\
2.8 \\
0\end{array}$ & $\begin{array}{c}52 \\
.9 \\
0\end{array}$ & $\begin{array}{c}62 \\
2.8 \\
0\end{array}$ & $\begin{array}{c}5 \mathrm{hr} \\
\mathrm{s} \\
25 \\
\text { min } \\
\text { utes }\end{array}$ \\
\hline
\end{tabular}

For $11^{\text {th }}$ September and $18^{\text {th }}$ October $\mathrm{V}_{\mathrm{dc}}$ remains greater than $81.71 \%$ and $82.42 \%$ of its rated value respectively for nearly 5.5 hours with cell temperature varying between $46-58^{\circ} \mathrm{C}$ in this duration. It can be observed from figure 2 and 3 that $\mathrm{P}_{\mathrm{dc}}$ varies in accordance to voltage variations until $\mathrm{V}_{\mathrm{dc}}$ attains nearly constant value and thereafter it varies in accordance to POA or $I_{d c}$ as $I_{d c}$ varies linearly with POA shown for $11^{\text {th }}$ September and $18^{\text {th }}$ October vide figure 4 and 5 respectively. $\mathrm{V}_{\mathrm{dc}}$ attains nearly high constant value for cell temperature around $46-46^{\circ} \mathrm{C}$ and remains high until cell temperature is high that is around $52-53{ }^{\circ} \mathrm{C}$ as shown vide figure 2 and 3 .

\subsection{Variation of $V_{d c}$, POA, cell temperature, \\ $I_{d c}$ and $P_{d c}$ with time for winter season}

The cell temperature varies in direct proportion to POA. In winters high POA is obtained for very short duration and correspondingly cell temperature is also low. Graphs depicting variations in $\mathrm{V}_{\mathrm{dc}}, \mathrm{POA}, \mathrm{P}_{\mathrm{dc}}$ and cell temperature with respect to time are shown in figure 6,7 and 8 for $13^{\text {th }}$ November, $22^{\text {nd }}$ December 2015 and $8^{\text {th }}$ January 2016 respectively. Variations in $\mathrm{I}_{\mathrm{dc}}$, POA and cell temperature with respect to time are shown in figure 9,10 and 11 for $13^{\text {th }}$ November, 22 $2^{\text {nd }}$ December 2015 and $8^{\text {th }}$ January 2016 respectively. The time duration for which $\mathrm{V}_{\mathrm{dc}}$ is constant in winter season is evaluated in table 3 . 


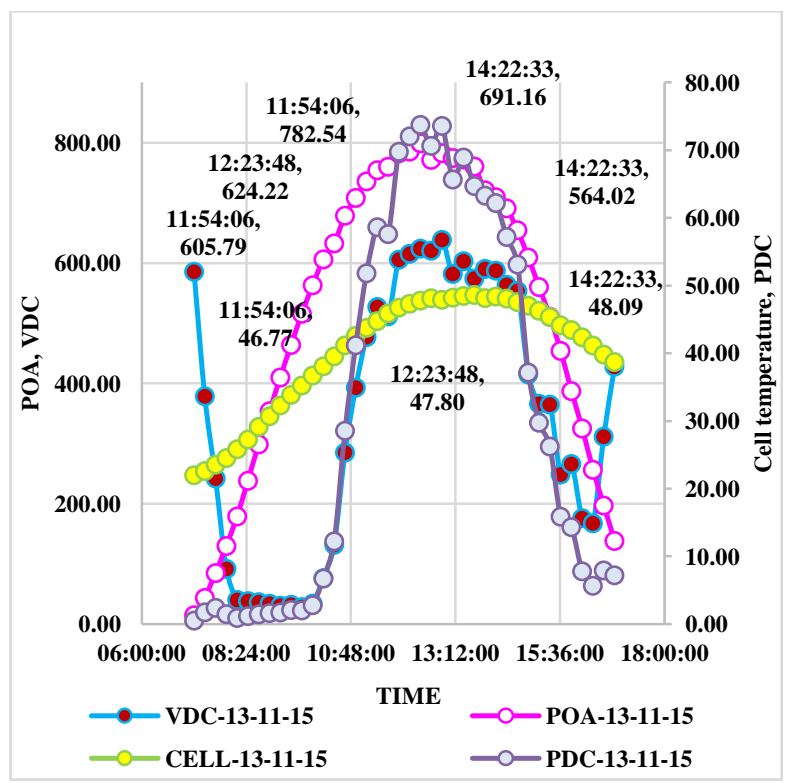

Figure 6 - Variation of $V_{d c}, P_{d c}$, POA and cell temperature with time for $13^{\text {th }}$ November 2015 .

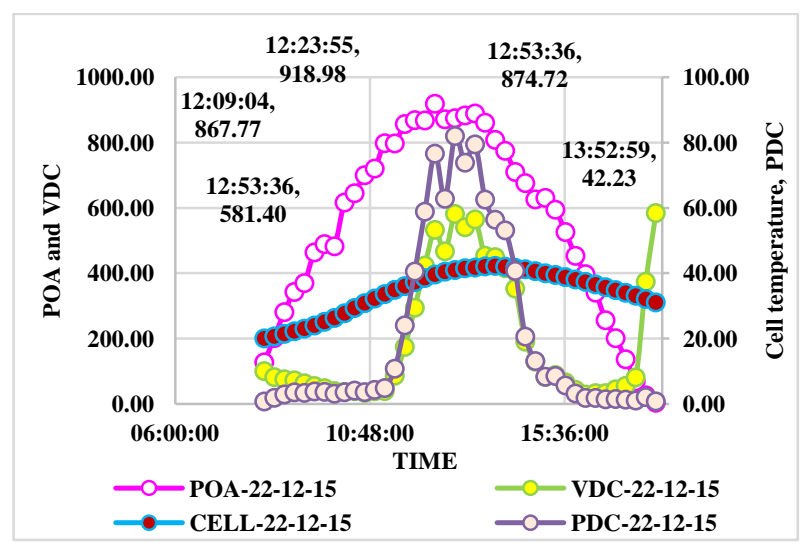

Figure 7- Variation of $V_{d c}, P_{d c}, P O A$ and cell temperature with time for $22^{\text {nd }}$ December 2015.

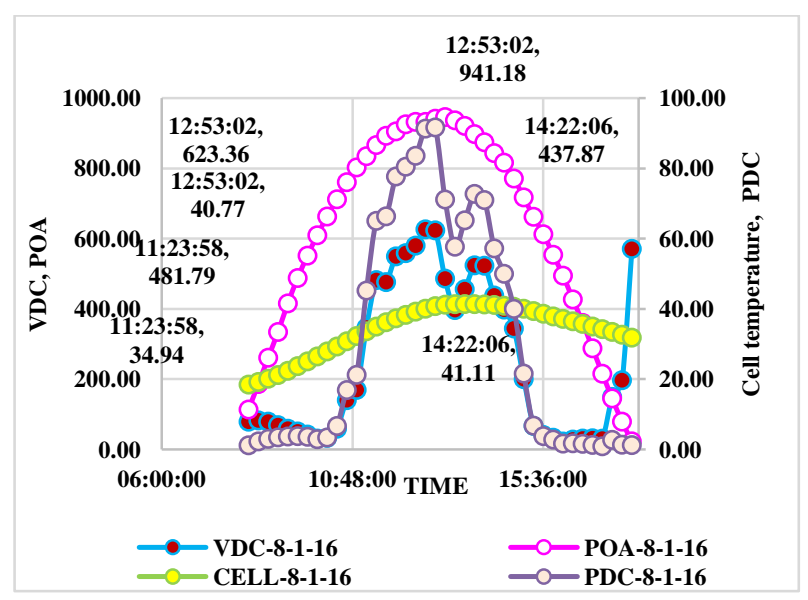

Figure 8 - Variation of $V_{d c}, P_{d c}$, POA and cell temperature with time for $8^{\text {th }}$ January 2016.

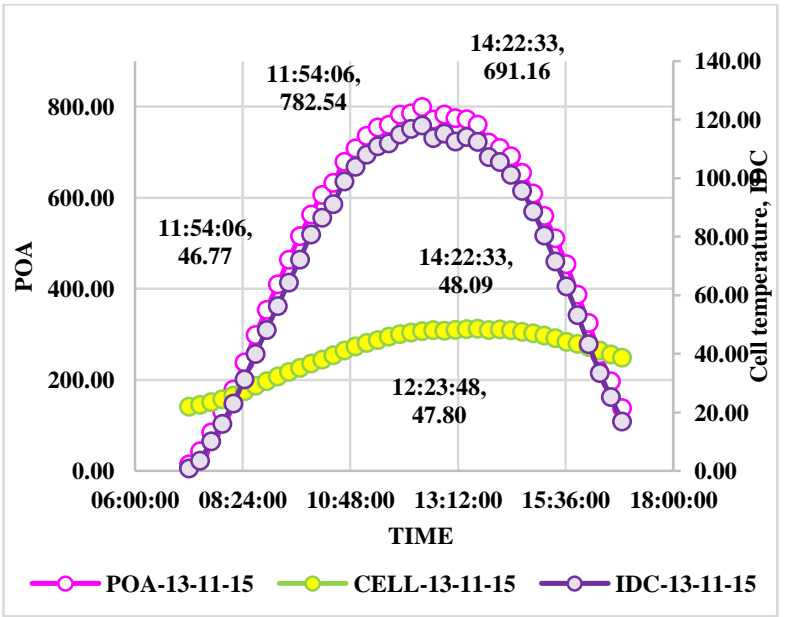

Figure 9- Variation of POA, $I_{d c}$, and cell temperature with time for $13^{\text {th }}$ November 2015.

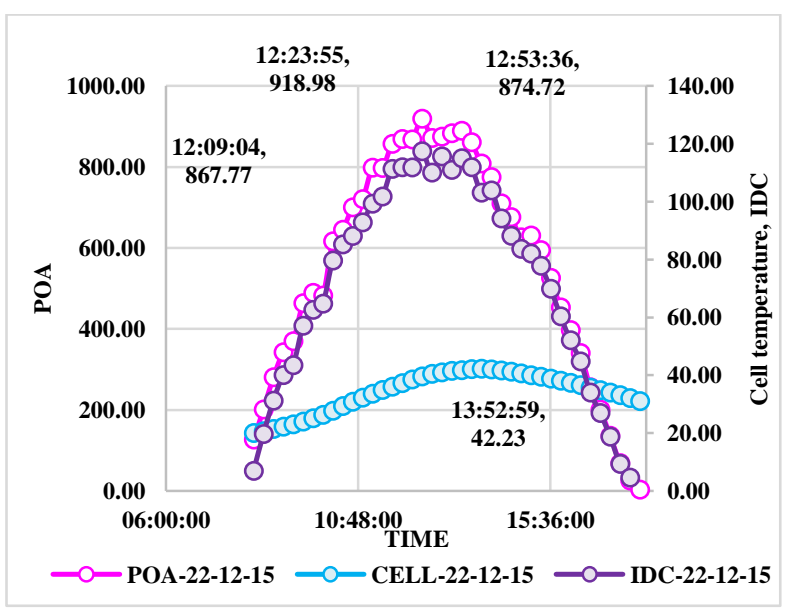

Figure 10- Variation of POA, $I_{\mathrm{dc}}$ and cell temperature with time for $22^{\text {nd }}$ December 2015.

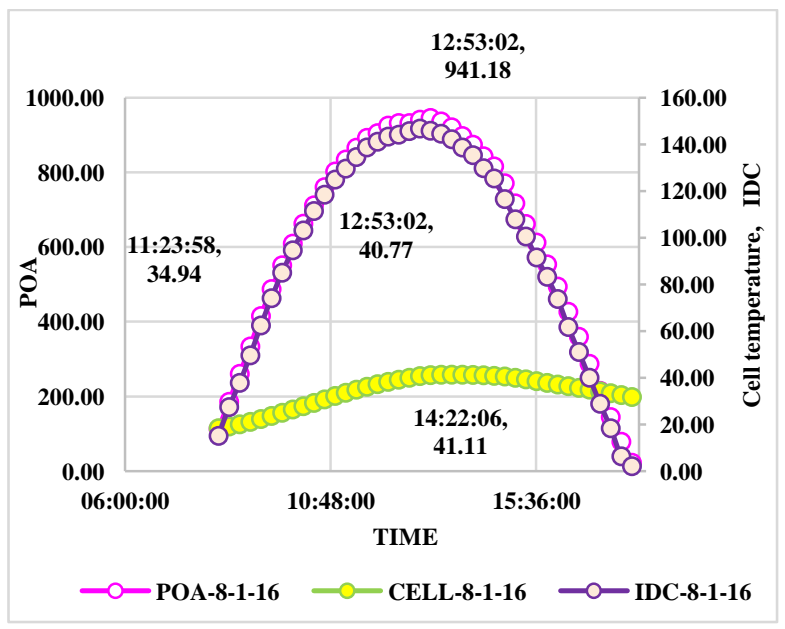

Figure 11- Variation of POA, $I_{d c}$ and cell temperature with time for $8^{\text {th }}$ January 2016. 
Table 3- Evaluation of the time duration for which $\mathbf{V}_{\mathrm{dc}}$ remains constant for the winter season

\begin{tabular}{|c|c|c|c|c|c|c|c|c|c|}
\hline $\begin{array}{l}\text { D } \\
\text { at } \\
\text { e }\end{array}$ & $\mathbf{X}_{1}$ & $\begin{array}{l}V_{1} \\
\text { in } \\
V\end{array}$ & $\begin{array}{l}\mathrm{T}_{1} \\
\text { in } \\
{ }^{\circ} \mathrm{C}\end{array}$ & $\begin{array}{c}\text { PO } \\
\mathbf{A}_{1} \\
\text { in } \\
\mathbf{W} / \\
\mathbf{m}^{2}\end{array}$ & $\mathbf{X}_{2}$ & $\begin{array}{l}V_{2} \\
\text { in } \\
V\end{array}$ & $\begin{array}{l}\mathrm{T}_{2} \\
\text { in } \\
{ }^{\mathbf{O}} \mathrm{C}\end{array}$ & $\begin{array}{c}\mathbf{P O} \\
\mathbf{A}_{2} \\
\text { in } \\
\mathbf{W} / \\
\mathbf{m}^{2}\end{array}$ & $\begin{array}{c}\mathbf{X}_{2} \\
- \\
\mathbf{X}_{1}\end{array}$ \\
\hline $\begin{array}{c}13 \\
- \\
11 \\
- \\
15\end{array}$ & $\begin{array}{l}\text { 11:5 } \\
4: 06\end{array}$ & $\begin{array}{c}60 \\
5.7 \\
9\end{array}$ & $\begin{array}{r}45 \\
9 \\
1\end{array}$ & $\begin{array}{c}76 \\
0.2 \\
4\end{array}$ & $\begin{array}{l}14: 2 \\
2: 33\end{array}$ & $\begin{array}{c}56 \\
4.0 \\
2\end{array}$ & $\begin{array}{l}48 \\
.0 \\
9\end{array}$ & $\begin{array}{c}69 \\
1.1 \\
6\end{array}$ & $\begin{array}{c}2 \\
\text { hou } \\
\text { rs } \\
20 \\
\text { min } \\
\text { utes }\end{array}$ \\
\hline $\begin{array}{c}22 \\
- \\
12 \\
- \\
15\end{array}$ & \multicolumn{9}{|c|}{$\begin{array}{l}\mathrm{V}_{\mathrm{dc}} \text { attains a maximum value of } 581.40 \mathrm{~V} \text { and does not } \\
\text { reach saturation point due to low temperature shown } \\
\text { vide figure 6. Maximum cell temperature is only } \\
42.23^{\circ} \mathrm{C} \text {. }\end{array}$} \\
\hline $\begin{array}{l}8- \\
1- \\
16\end{array}$ & \multicolumn{9}{|c|}{$\begin{array}{c}\mathrm{V}_{\mathrm{dc}} \text { attains maximum value of } 623.36 \mathrm{~V} \text { at cell } \\
\text { temperature } 40.77^{\circ} \mathrm{C} \text {, POA } 914.18 \mathrm{~W} / \mathrm{m}^{2} \text { but soon drops } \\
\text { rapidly with decreasing POA due to low temperature } \\
\text { shown vide figure } 7 .\end{array}$} \\
\hline
\end{tabular}

In November $\mathrm{V}_{\mathrm{dc}}$ is nearly constant for very short duration of about 2 hours 20 minutes when the cell temperature is comparatively higher $\left(47-48^{\circ} \mathrm{C}\right)$ and drops to $76.7 \%$ of its rated value at cell temperature $48^{\circ} \mathrm{C}$ shown vide figure 6 . In the month of December and January, the cell temperature is very low, around $40-43^{\circ} \mathrm{C}, \mathrm{V}_{\mathrm{dc}}$ does not reach point of saturation and so constant value of $\mathrm{V}_{\mathrm{dc}}$ is not maintained and $\mathrm{P}_{\mathrm{dc}}$ varies in accordance to $\mathrm{V}_{\mathrm{dc}}$ as can be observed from figure 7 and 8. The current varies in direct proportion to POA shown vide figure 9,10 and 11 with no significant effect of cell temperature.

\subsection{Variation of $V_{d c}$, POA, cell temperature, $\mathbf{I}_{\mathrm{dc}}$ and $\mathbf{P}_{\mathrm{dc}}$ with time for spring season}

The temperature is moderate varying from $40-53^{\circ} \mathrm{C}$ with high POA for reasonable duration. Graphs depicting variations in $\mathrm{V}_{\mathrm{dc}}, \mathrm{POA}, \mathrm{P}_{\mathrm{dc}}$ and cell temperature for $22^{\text {nd }}$ February and $27^{\text {th }}$ March 2016 are shown in figure 12 and 13 respectively. Variations in $\mathrm{I}_{\mathrm{dc}}$, POA, and cell temperature with respect to time for $22^{\text {nd }}$ February and $27^{\text {th }}$ March 2016 are shown in figure 14 and 15 respectively. The time duration for which $V_{d c}$ is constant is evaluated in table 4 .

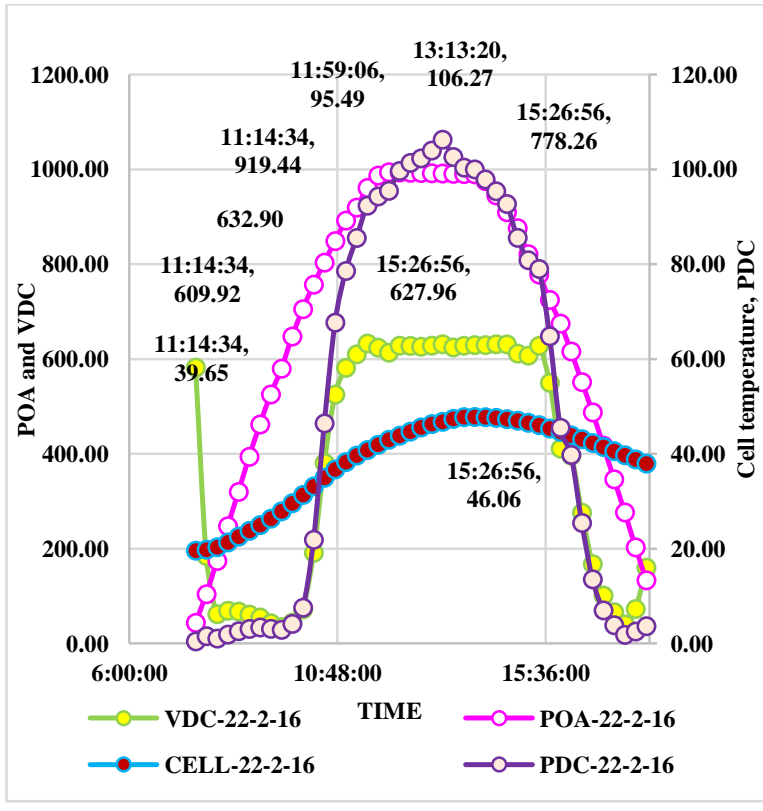

Figure 12- Variation of $V_{d c}, P_{d c}, P O A$ and cell temperature with time for $\mathbf{2 2}^{\text {nd }}$ February

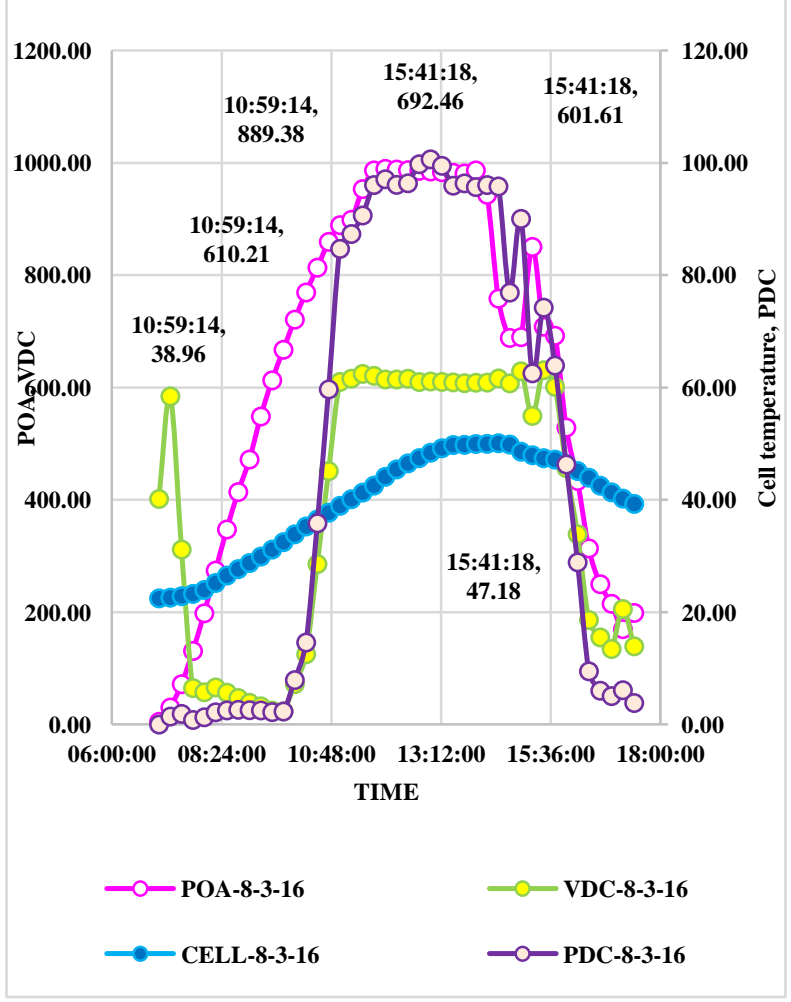

Figure 13- Variation of $V_{d c}, P_{d c}, P O A$ and cell temperature with time for $8^{\text {th }}$ March 2016. 


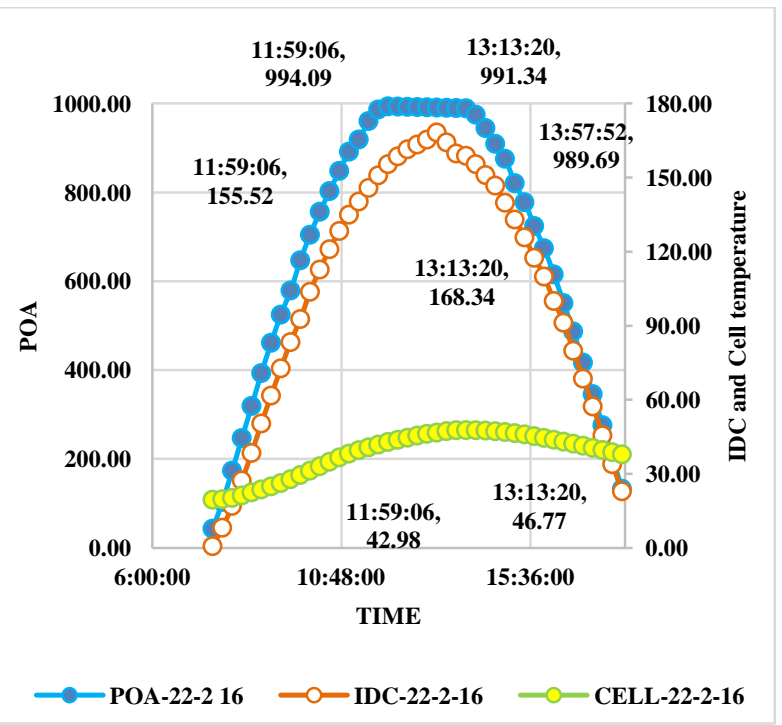

Figure 14- Variation of POA, $I_{d c}$ and cell temperature with time for $2^{\text {nd }}$ February 2016.

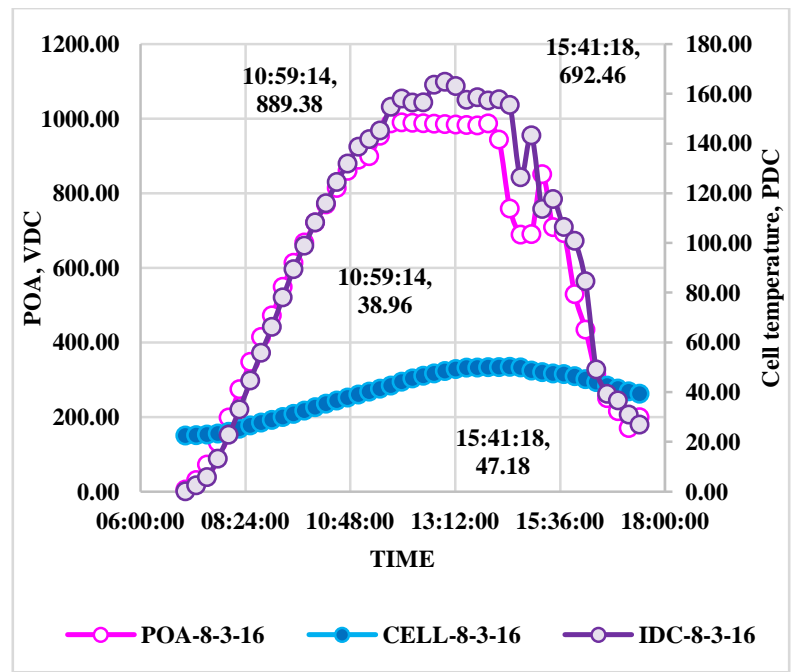

Figure 15- Variation of POA, $I_{d c}$ and cell temperature with time for $8^{\text {th }}$ March 2016.

Table 4- Evaluation of the time duration for which $V_{d c}$ remains constant for the spring season

\begin{tabular}{|c|c|c|c|c|c|c|c|c|c|}
\hline $\begin{array}{c}\text { D } \\
\text { at } \\
\text { e }\end{array}$ & $\mathbf{X}_{1}$ & $\begin{array}{l}V_{1} \\
\text { in } \\
V\end{array}$ & $\begin{array}{l}\mathrm{T}_{1} \\
\text { in } \\
{ }^{\circ} \mathrm{C}\end{array}$ & $\begin{array}{c}\text { PO } \\
\mathbf{A}_{1} \\
\text { in } \\
\mathbf{W} / \\
\mathbf{m}^{2}\end{array}$ & $\mathbf{X}_{2}$ & $\begin{array}{l}V_{2} \\
\text { in } \\
V\end{array}$ & $\begin{array}{l}\mathrm{T}_{2} \\
\text { in } \\
{ }^{\circ} \mathrm{C}\end{array}$ & $\begin{array}{c}\mathbf{P O} \\
\mathbf{A}_{2} \\
\text { in } \\
\mathbf{W} / \\
\mathbf{m}^{2}\end{array}$ & $\begin{array}{c}\mathbf{X}_{2} \\
- \\
\mathbf{X}_{1}\end{array}$ \\
\hline $\begin{array}{c}22 \\
- \\
2- \\
16\end{array}$ & $\begin{array}{l}11: 1 \\
4: 34\end{array}$ & $\begin{array}{c}60 \\
9.9 \\
2\end{array}$ & $\begin{array}{c}39 \\
.6 \\
5\end{array}$ & $\begin{array}{c}91 \\
9.4 \\
4\end{array}$ & $\begin{array}{l}15: 2 \\
6: 56\end{array}$ & $\begin{array}{c}62 \\
7.9 \\
6\end{array}$ & $\begin{array}{c}46 \\
.0 \\
6\end{array}$ & $\begin{array}{c}77 \\
8.2 \\
6\end{array}$ & $\begin{array}{c} \\
\text { hrs } \\
12 \\
\text { min } \\
\text { utes }\end{array}$ \\
\hline $\begin{array}{l}8- \\
3- \\
16\end{array}$ & $\begin{array}{l}10: 5 \\
9: 14\end{array}$ & $\begin{array}{c}61 \\
0.2 \\
1\end{array}$ & $\begin{array}{c}38 \\
.9 \\
6\end{array}$ & $\begin{array}{c}88 \\
9.3 \\
8\end{array}$ & $\begin{array}{l}15: 4 \\
1: 18\end{array}$ & $\begin{array}{c}60 \\
1.6 \\
1\end{array}$ & $\begin{array}{c}47 \\
.1 \\
8\end{array}$ & $\begin{array}{c}69 \\
2.4 \\
6\end{array}$ & $\begin{array}{c}4 \mathrm{hr} \\
\mathrm{s} \\
40 \\
\text { min } \\
\text { utes }\end{array}$ \\
\hline
\end{tabular}

On $22^{\text {nd }}$ February $\mathrm{V}_{\mathrm{dc}}$ remains constant for about 4 hrs 12 minutes and that too when POA is very high as shown vide figure 12. At lower temperature $\left(39.65^{\circ} \mathrm{C}\right)$ higher value of POA $\left(919.44 \mathrm{~W} / \mathrm{m}^{2}\right)$ is required to reach point of saturation. As cell temperature varies between $40-46^{\circ} \mathrm{C} . \mathrm{V}_{\mathrm{dc}}$ varies between $86 \%-85 \%$ of its rated value. On $8^{\text {th }}$ March $V_{d c}$ remains constant for about $4 \mathrm{hrs} 40$ minutes as shown vide figure 13 . As the cell temperature varies between $39-48^{\circ} \mathrm{C} \mathrm{V}_{\mathrm{dc}}$ varies nearly between $85 \%$ to $82 \%$ of its rated value. It is observed that $\mathrm{V}_{\mathrm{dc}}$ drops rapidly as cell temperature drops to 46 ${ }^{\circ} \mathrm{C}$ and $47{ }^{\circ} \mathrm{C}$ even for very high POA $778.26 \mathrm{~W} / \mathrm{m}^{2}$ and $692.46 \mathrm{~W} / \mathrm{m}^{2}$ on $22^{\text {nd }}$ February and $8^{\text {th }}$ March respectively showing that high cell temperature is essential for high and nearly constant $\mathrm{V}_{\mathrm{dc}}$. Further, $\mathrm{P}_{\mathrm{dc}}$ varies in accordance to POA and correspondingly $\mathrm{I}_{\mathrm{dc}}$ as shown vide figure 12,13,14 and 15 only in the duration when $\mathrm{V}_{\mathrm{dc}}$ remains constant. The POA is nearly constant from 11:59:06 to $13: 57: 52$ on $22^{\text {nd }}$ February shown vide figure 14 and even though POA decreases from $994.09 \mathrm{~W} / \mathrm{m}^{2}$ to $991.34 \mathrm{~W} / \mathrm{m}^{2}$ with corresponding increase in cell temperature from $42.98^{\circ} \mathrm{C}$ to $46.77^{\circ} \mathrm{C}, \mathrm{I}_{\mathrm{dc}}$ increases from $155.52 \mathrm{~A}$ to $168.34 \mathrm{~A}, \mathrm{P}_{\mathrm{dc}}$ increases from $95.49 \mathrm{~kW}$ to 106.27 $\mathrm{kW}$ due to positive effect of cell temperature on $\mathrm{I}_{\mathrm{dc}}$ which is normally not visible as variations in irradiance are significant compared to variations in cell temperature and significant positive effect of cell temperature on $\mathrm{I}_{\mathrm{dc}}$ is observed only when variation in cell temperature are substantial compared to variations in POA.

\subsection{Variation of $V_{d c}$, POA, cell temperature,} $I_{d c}$ and $P_{d c}$ with time for summers

Although June to August are in general rainy season but sometimes it rains only in July and August. The day considered for analysis, $4^{\text {th }}$ June and $11^{\text {th }}$ July represents clear sunny day and so have been considered in summer season. The variations in $\mathrm{V}_{\mathrm{dc}}, \mathrm{POA}, \mathrm{P}_{\mathrm{dc}}$ and cell temperature with respect to time for $12^{\text {th }}$ April, $13^{\text {th }}$ May, $4^{\text {th }}$ June and $11^{\text {th }}$ July are shown in figure $16,17,18$ and 19 respectively. The variations in $\mathrm{I}_{\mathrm{dc}}$, POA and cell temperature with respect to time for $12^{\text {th }}$ April, $13^{\text {th }}$ May, $4^{\text {th }}$ June and $11^{\text {th }}$ July are shown in figure 20,21, 22 and 23 respectively. The time duration for which $\mathrm{V}_{\mathrm{dc}}$ is constant is evaluated in table 5 .

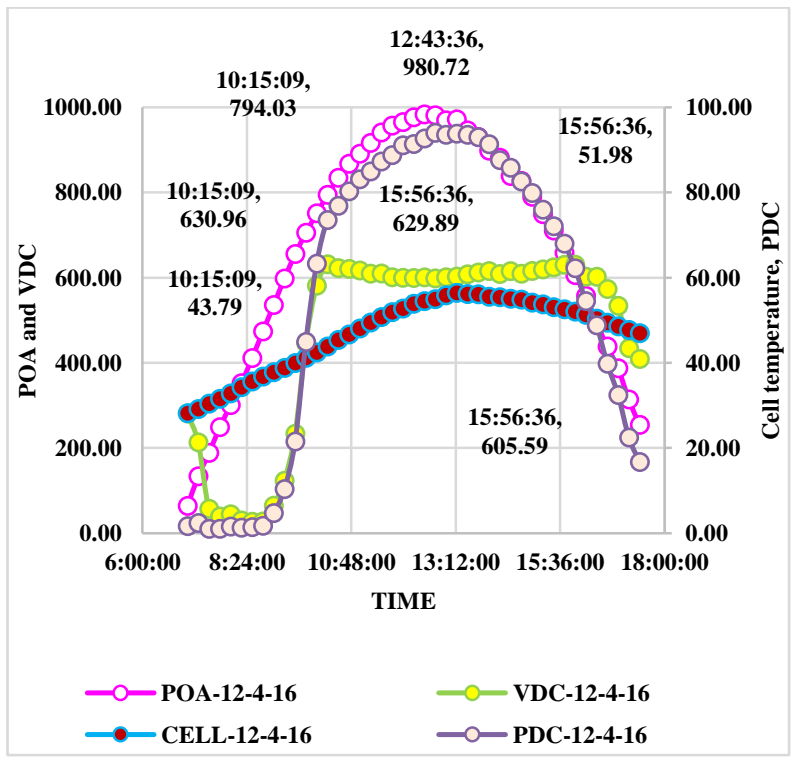

Figure 16-Variation of $V_{d c}, P_{d c}, P O A$ and cell temperature with time for $12^{\text {th }}$ April 2016. 


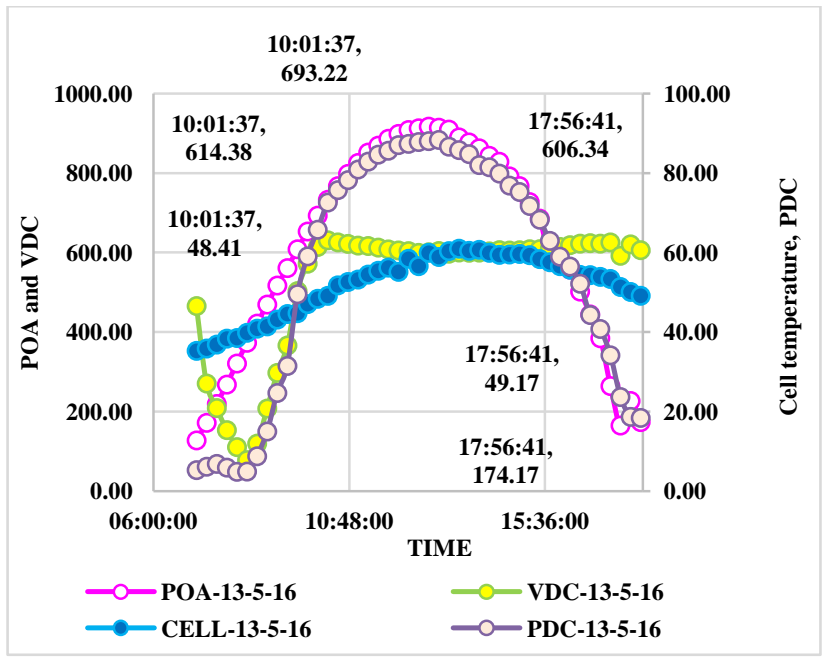

Figure 17 - Variation of $V_{d c}, P_{d c}, P O A$ and cell temperature with time for $13^{\text {th }}$ May 2016 .

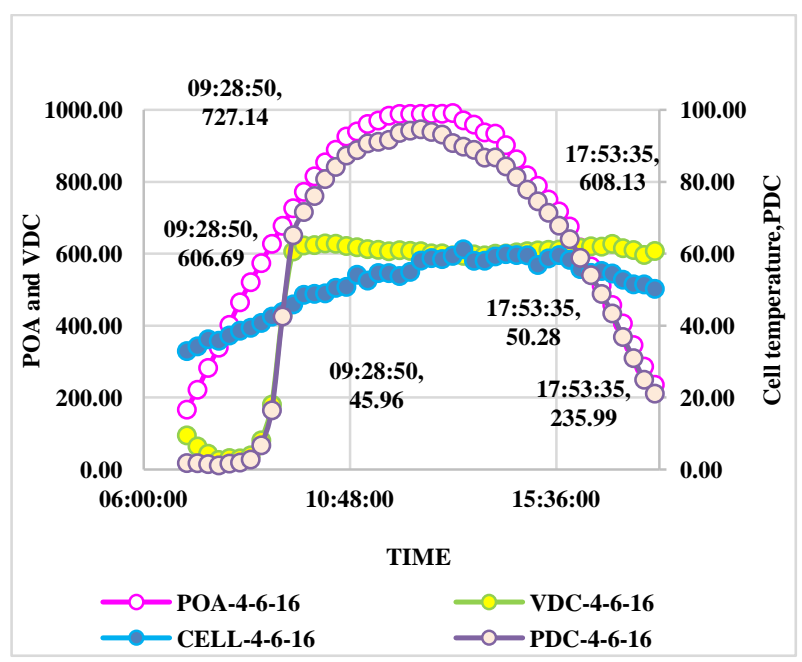

Figure 18- Variation of $V_{d c}, P_{d c}, P O A$ and cell temperature with time for $4^{\text {th }}$ June 2016.

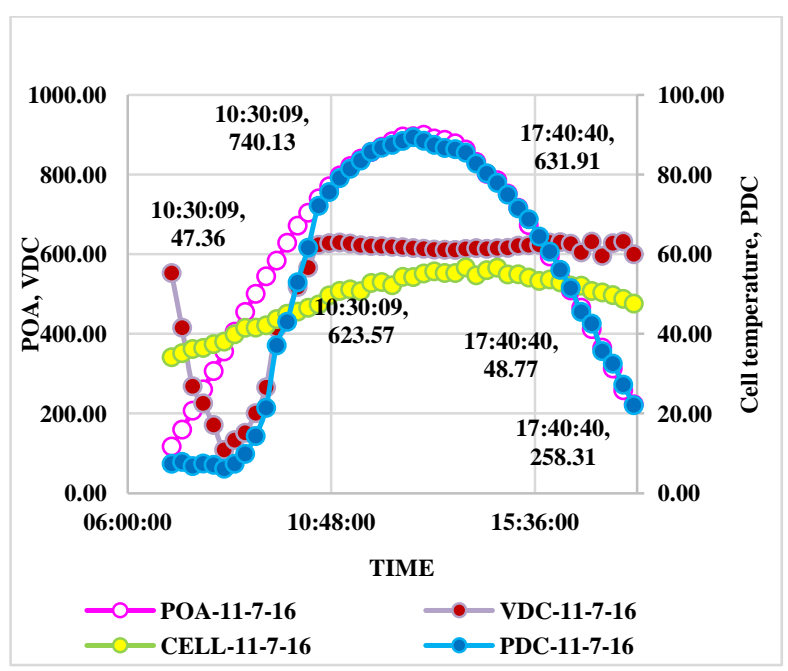

Figure 19 - Variation of $V_{d c}, P_{d c}, P O A$ and cell temperature with time for $11^{\text {th }}$ July 2016 .

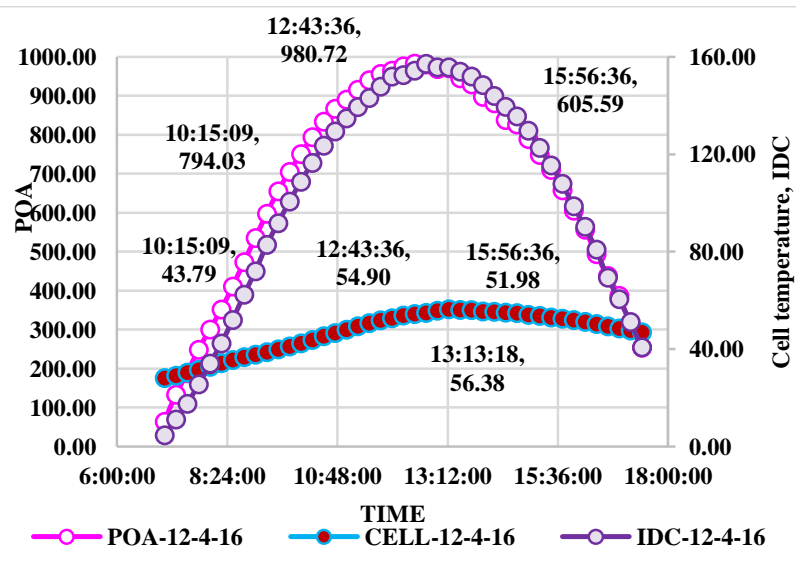

Figure 20- Variation of POA, $I_{d c}$ and cell temperature with time for $12^{\text {th }}$ April 2016.

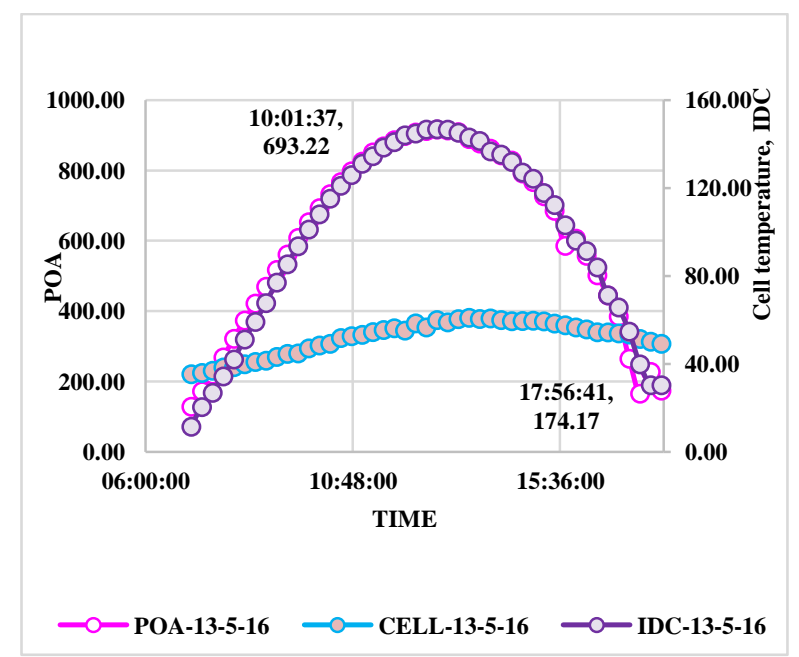

Figure 21- Variation of POA, $I_{d c}$ and cell temperature with time for $13^{\text {th }}$ May 2016.

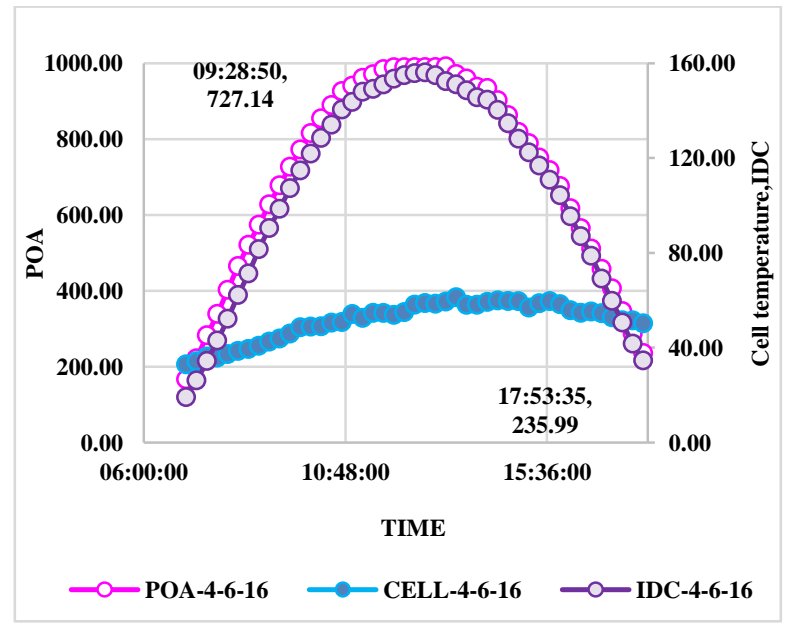

Figure 22- Variation of POA, $I_{d c}$ and cell temperature with time for $4^{\text {th }}$ June 2016. 


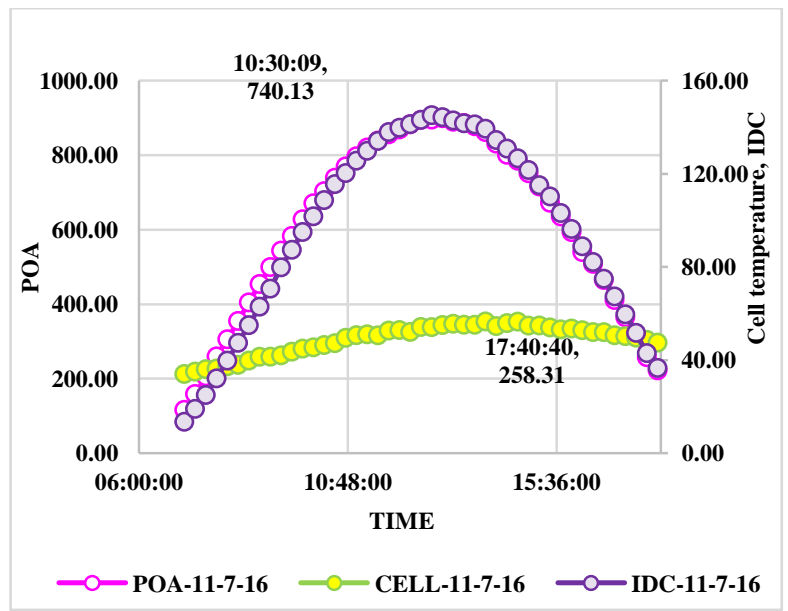

Figure 23- Variation of POA, $I_{d c}$ and cell temperature with time for $11^{\text {th }}$ July 2016.

Table 5 - Evaluation of the time duration $\left(X_{2}-X_{1}\right)$ for which $V_{d c}$ remains constant during summer season

\begin{tabular}{|c|c|c|c|c|c|c|c|c|c|}
\hline $\begin{array}{c}\text { D } \\
\text { at } \\
\text { e }\end{array}$ & $\mathbf{X}_{1}$ & $\begin{array}{l}V_{1} \\
\text { in } \\
V\end{array}$ & $\begin{array}{l}\mathrm{T}_{1} \\
\text { in } \\
{ }^{\circ} \mathrm{C}\end{array}$ & $\begin{array}{c}\text { PO } \\
\mathbf{A}_{1} \\
\text { in } \\
\mathbf{W} / \\
\mathbf{m}^{2}\end{array}$ & $\mathbf{X}_{2}$ & $\begin{array}{l}V_{2} \\
\text { in } \\
V\end{array}$ & $\begin{array}{l}\mathrm{T}_{2} \\
\text { in } \\
{ }^{\circ} \mathrm{C}\end{array}$ & $\begin{array}{c}\text { PO } \\
\mathbf{A}_{2} \\
\text { in } \\
\mathbf{W} / \\
\mathbf{m}^{2}\end{array}$ & $\begin{array}{c}\mathbf{X}_{2} \\
- \\
\mathbf{X}_{1}\end{array}$ \\
\hline $\begin{array}{c}12 \\
- \\
4- \\
16\end{array}$ & $\begin{array}{l}10: 1 \\
5: 09\end{array}$ & $\begin{array}{c}63 \\
0.9 \\
6\end{array}$ & $\begin{array}{c}43 \\
.7 \\
9\end{array}$ & $\begin{array}{c}79 \\
4.0 \\
3\end{array}$ & $\begin{array}{l}15: 5 \\
6: 36\end{array}$ & $\begin{array}{c}62 \\
9.8 \\
9\end{array}$ & $\begin{array}{c}51 \\
.9 \\
8\end{array}$ & $\begin{array}{c}60 \\
5.5 \\
9\end{array}$ & $\begin{array}{c}5 \\
\text { hrs } \\
40 \\
\text { min } \\
\text { utes }\end{array}$ \\
\hline $\begin{array}{c}13 \\
- \\
5- \\
16\end{array}$ & $\begin{array}{l}10: 0 \\
1: 37\end{array}$ & $\begin{array}{c}61 \\
4.3 \\
8\end{array}$ & $\begin{array}{c}48 \\
.4 \\
1\end{array}$ & $\begin{array}{c}69 \\
3.2 \\
2\end{array}$ & $\begin{array}{l}17: 5 \\
6: 41\end{array}$ & $\begin{array}{c}60 \\
6.3 \\
4\end{array}$ & $\begin{array}{l}49 \\
.1 \\
7\end{array}$ & $\begin{array}{c}17 \\
4.1 \\
7\end{array}$ & $\begin{array}{c}8 \\
\text { hou } \\
\text { rs }\end{array}$ \\
\hline $\begin{array}{l}4- \\
6- \\
16\end{array}$ & $\begin{array}{c}9: 28 \\
: 50\end{array}$ & $\begin{array}{c}60 \\
6.6 \\
9\end{array}$ & $\begin{array}{c}45 \\
.9 \\
6\end{array}$ & $\begin{array}{c}72 \\
7.1 \\
4\end{array}$ & $\begin{array}{l}17: 5 \\
3: 35\end{array}$ & $\begin{array}{c}60 \\
8.1 \\
3\end{array}$ & $\begin{array}{c}50 \\
.2 \\
8\end{array}$ & $\begin{array}{c}23 \\
5.9 \\
9\end{array}$ & $\begin{array}{c}8 \\
\text { hou } \\
\text { rs } \\
20 \\
\text { min } \\
\text { utes }\end{array}$ \\
\hline $\begin{array}{c}11 \\
- \\
7- \\
16\end{array}$ & $\begin{array}{l}10: 3 \\
0: 09\end{array}$ & $\begin{array}{c}62 \\
3.5 \\
7\end{array}$ & $\begin{array}{l}47 \\
.3 \\
6\end{array}$ & $\begin{array}{c}74 \\
0.1 \\
3\end{array}$ & $\begin{array}{l}17: 4 \\
0: 40\end{array}$ & $\begin{array}{c}63 \\
1.9 \\
1\end{array}$ & $\begin{array}{l}48 \\
.7 \\
7\end{array}$ & $\begin{array}{c}25 \\
8.3 \\
1\end{array}$ & $\begin{array}{c}7 \\
\text { hou } \\
\text { rs } \\
10 \\
\text { min } \\
\text { utes }\end{array}$ \\
\hline
\end{tabular}

In summers when the temperature is very high $\mathrm{V}_{\mathrm{dc}}$ is also high and nearly constant for about 8 hours irrespective of irradiance showing that at high cell temperature $\mathrm{V}_{\mathrm{dc}}$ becomes independent of irradiance, the most significant positive effect of high cell temperature. In the time duration when $\mathrm{V}_{\mathrm{dc}}$ is constant the $\mathrm{P}_{\mathrm{dc}}$ curve follows POA curve and correspondingly $\mathrm{I}_{\mathrm{dc}}$ curve as shown vide figure 16-19. The dc current varies in direct proportion to irradiance and is verified by figures $20-23$.

To analyse the effect and role of cell temperature and irradiance on energy yield, the average values of POA, $T_{c}$, $\mathrm{V}_{\mathrm{dc}}, \mathrm{I}_{\mathrm{dc}}$ and $\mathrm{P}_{\mathrm{dc}}$ are evaluated in table 6 and are represented by
$\mathrm{POA}_{\mathrm{av}}, \mathrm{T}_{\mathrm{av}}, \mathrm{V}_{\mathrm{av}}, \mathrm{I}_{\mathrm{av}}$ and $\mathrm{P}_{\mathrm{av}}$ respectively. The energy yield and maximum dc power $\mathrm{P}_{\mathrm{dcmax}}$ of corresponding day are also evaluated.

Table 6- Evaluation of average value of various technological parameters affecting energy yield.

\begin{tabular}{|c|c|c|c|c|c|c|c|}
\hline $\begin{array}{c}\text { Dat } \\
\mathrm{e}\end{array}$ & $\begin{array}{c}\mathrm{P}_{\mathrm{dcma}} \\
\mathrm{x} \\
\mathrm{in} \\
\mathrm{kW}\end{array}$ & $\begin{array}{l}\mathrm{POA} \\
\text { av in } \\
\mathrm{W} / \mathrm{m} \\
2\end{array}$ & $\begin{array}{l}\mathrm{T}_{\mathrm{av}} \\
\text { in } \\
{ }^{\circ} \mathrm{C} .\end{array}$ & $\mathrm{V}_{\mathrm{av}}$ & $\mathrm{I}_{\mathrm{av}}$ & $\mathrm{P}_{\mathrm{av}}$ & $\begin{array}{c}\text { Energy } \\
\text { yield } \\
\text { of the } \\
\text { day in } \\
\mathrm{kWh} / \mathrm{d} \\
\text { ay }\end{array}$ \\
\hline $\begin{array}{c}11- \\
9- \\
15\end{array}$ & $\begin{array}{c}88.4 \\
1\end{array}$ & $\begin{array}{c}622 . \\
20\end{array}$ & $\begin{array}{c}48.4 \\
9\end{array}$ & $\begin{array}{c}490 . \\
98\end{array}$ & $\begin{array}{c}90.7 \\
2\end{array}$ & $\begin{array}{c}49.7 \\
8\end{array}$ & $\begin{array}{c}2240.1 \\
1\end{array}$ \\
\hline $\begin{array}{l}18- \\
10- \\
15\end{array}$ & $\begin{array}{c}93.8 \\
5\end{array}$ & $\begin{array}{c}608 . \\
22\end{array}$ & $\begin{array}{c}47.5 \\
3\end{array}$ & $\begin{array}{c}495 . \\
02\end{array}$ & $\begin{array}{c}93.9 \\
8\end{array}$ & $\begin{array}{c}52.1 \\
4\end{array}$ & $\begin{array}{c}2346.2 \\
8\end{array}$ \\
\hline $\begin{array}{l}13- \\
11- \\
15\end{array}$ & $\begin{array}{c}73.7 \\
6\end{array}$ & $\begin{array}{c}515 . \\
49\end{array}$ & $\begin{array}{c}40.1 \\
0\end{array}$ & $\begin{array}{c}347 . \\
02\end{array}$ & $\begin{array}{c}74.0 \\
5\end{array}$ & $\begin{array}{c}30.6 \\
0\end{array}$ & $\begin{array}{c}1224.0 \\
2\end{array}$ \\
\hline $\begin{array}{l}22- \\
12- \\
15\end{array}$ & $\begin{array}{c}82.0 \\
1\end{array}$ & $\begin{array}{c}553 . \\
77\end{array}$ & $\begin{array}{c}34.2 \\
0\end{array}$ & $\begin{array}{c}196 . \\
95\end{array}$ & $\begin{array}{c}72.8 \\
7\end{array}$ & $\begin{array}{c}20.8 \\
7\end{array}$ & 834.78 \\
\hline $\begin{array}{c}08- \\
01- \\
16\end{array}$ & $\begin{array}{c}91.6 \\
3\end{array}$ & $\begin{array}{c}617 . \\
62\end{array}$ & $\begin{array}{c}33.9 \\
5\end{array}$ & $\begin{array}{c}252 . \\
41\end{array}$ & $\begin{array}{c}94.3 \\
1\end{array}$ & $\begin{array}{c}30.1 \\
2\end{array}$ & $\begin{array}{c}1204.8 \\
6\end{array}$ \\
\hline $\begin{array}{c}22- \\
02- \\
16\end{array}$ & $\begin{array}{c}106 . \\
27\end{array}$ & $\begin{array}{c}675 . \\
23\end{array}$ & $\begin{array}{c}38.2 \\
8\end{array}$ & $\begin{array}{c}382 . \\
23\end{array}$ & $\begin{array}{c}105 . \\
29\end{array}$ & $\begin{array}{c}50.4 \\
6\end{array}$ & $\begin{array}{c}2169.8 \\
6\end{array}$ \\
\hline $\begin{array}{c}08- \\
03- \\
16\end{array}$ & $\begin{array}{c}100 . \\
65\end{array}$ & $\begin{array}{c}627 . \\
45\end{array}$ & $\begin{array}{c}39.4 \\
0\end{array}$ & $\begin{array}{c}383 . \\
30\end{array}$ & $\begin{array}{c}99.8 \\
8\end{array}$ & $\begin{array}{c}47.5 \\
0\end{array}$ & $\begin{array}{c}2042.4 \\
3\end{array}$ \\
\hline $\begin{array}{c}12- \\
04- \\
16\end{array}$ & $\begin{array}{c}93.9 \\
6\end{array}$ & $\begin{array}{c}668 . \\
08\end{array}$ & $\begin{array}{c}46.8 \\
4\end{array}$ & $\begin{array}{c}465 . \\
21\end{array}$ & $\begin{array}{c}102 . \\
52\end{array}$ & $\begin{array}{c}55.6 \\
4\end{array}$ & $\begin{array}{c}2392.7 \\
2\end{array}$ \\
\hline $\begin{array}{c}13- \\
05- \\
16\end{array}$ & $\begin{array}{c}88.3 \\
4\end{array}$ & $\begin{array}{c}617 . \\
50\end{array}$ & $\begin{array}{c}51.8 \\
5\end{array}$ & $\begin{array}{c}522 . \\
65\end{array}$ & $\begin{array}{c}97.7 \\
0\end{array}$ & $\begin{array}{c}55.3 \\
7\end{array}$ & $\begin{array}{c}2491.8 \\
4\end{array}$ \\
\hline $\begin{array}{c}04- \\
06- \\
16\end{array}$ & $\begin{array}{c}94.6 \\
8\end{array}$ & $\begin{array}{c}707 . \\
07\end{array}$ & $\begin{array}{c}51.3 \\
8\end{array}$ & $\begin{array}{c}497 . \\
93\end{array}$ & $\begin{array}{c}106 . \\
91\end{array}$ & $\begin{array}{c}59.1 \\
2\end{array}$ & $\begin{array}{c}2660.4 \\
4\end{array}$ \\
\hline $\begin{array}{l}11- \\
07- \\
16\end{array}$ & $\begin{array}{c}89.3 \\
8\end{array}$ & $\begin{array}{c}612 . \\
55\end{array}$ & $\begin{array}{c}48.8 \\
9\end{array}$ & $\begin{array}{c}524 . \\
97\end{array}$ & $\begin{array}{c}96.1 \\
7\end{array}$ & $\begin{array}{c}54.4 \\
1\end{array}$ & $\begin{array}{c}2448.5 \\
3\end{array}$ \\
\hline
\end{tabular}

The table 6 shows that when both POA and cell temperature are high as for $4^{\text {th }}$ June average $V_{d c}$ and average $I_{d c}$ are maximum leading to maximum energy yield. Minimum energy yield is obtained on $22^{\text {nd }}$ December due to very low cell temperature despite higher POA as compared to $13^{\text {th }}$ November. Although maximum dc power of $106.27 \mathrm{~kW}$ is obtained on $22^{\text {nd }}$ February due to high POA for long duration and correspondingly high average POA but due to low average cell temperature and correspondingly low average $\mathrm{V}_{\mathrm{dc}}$, the average dc power and energy yield are low as compared to summers and post monsoon season. Average 
POA and average cell temperature on $13^{\text {th }}$ May are high, the result is that average $\mathrm{V}_{\mathrm{dc}}$ on $13^{\text {th }}$ May is much higher as compared to $22^{\text {nd }}$ February although there is small difference in average $I_{d c}$ and consequently energy yield on $13^{\text {th }}$ May is far greater than energy yield on $22^{\text {nd }}$ February. Comparing results of $12^{\text {th }}$ April and $13^{\text {th }}$ May, average POA and correspondingly average current are greater on $12^{\text {th }}$ April but due to comparatively higher average temperature on $13^{\text {th }}$ May, the average $V_{d c}$ and correspondingly energy yield on $13^{\text {th }}$ May are far greater than $12^{\text {th }}$ April showing that high cell temperature plays significant positive role on energy yield. Minimum energy yield is obtained in winters due to extremely low temperature and low irradiance and correspondingly lower average $V_{d c}$ and low average $I_{d c}$ respectively.

\section{RESULTS}

The dc power is product of dc voltage and dc current. The maximum dc voltage of the array used for investigation is $735.36 \mathrm{~V}$ while the maximum current is $161.4 \mathrm{~A}$. The ratio of maximum voltage to current is approximately 4.55 , the result is that variations in voltage are more significant compared to variation in current. The affect is clearly verified vide figure $2,3,6,7,8,12,13$ and 16-19 all which show that variations in $\mathrm{P}_{\mathrm{dc}}$ are dominated by $\mathrm{V}_{\mathrm{dc}}$ rather than current as $\mathrm{P}_{\mathrm{dc}}$ curve follows $V_{d c}$ curve as long as $V_{d c}$ does not attain high constant value but once $\mathrm{V}_{\mathrm{dc}}$ becomes constant $\mathrm{P}_{\mathrm{dc}}$ curve follows POA and correspondingly $\mathrm{I}_{\mathrm{dc}}$ curve. The results are further verified via table 6 which shows higher the average cell temperature, higher is the dc voltage and corresponding higher is the energy yield. In winters when the cell temperature is low the $P_{d c}$ curve continues to follow the $V_{d c}$ curve as dc voltage does not attain constant high value.

$\mathrm{I}_{\mathrm{dc}}$ varies in direct proportion to POA as verified vide figure $4,5,9-11,14,15$ and 20-23. The variations in POA are substantial compared to variations in cell temperature, the result is that positive effect of cell temperature on $\mathrm{I}_{\mathrm{dc}}$ is visible only at nearly constant POA that is when variations in cell temperature are significant compared to variations in POA.

The voltage variations are dominated by cell temperature becoming independent of POA at high cell temperature and since the dc power is affected substantially by voltage variation rather than current variations it can be concluded that high cell temperature has defining positive role on dc power and high energy yield in contrast to literature and research papers all which show negative effect of cell temperature.

However, despite the defining positive role of high cell temperature the importance of irradiance cannot be overlooked. Once $V_{d c}$ attains constant high value it is the irradiance that plays the dominating role with the dc power varying in direct proportion to POA. Thus, although cell temperature plays the defining positive role but both high cell temperature and high irradiance are essential for high dc power and correspondingly energy yield.

\section{CONCLUSION}

The analysis of multicrystalline solar PV module for the climatic conditions of Western Rajasthan shows cell temperature plays defining positive role on the high average dc power and high energy yield in contrast to literature and research papers $[1,2,3,4,5,6,7,8,9,10]$. Although maximum dc power is achieved at average cell temperature of $38.28^{\circ} \mathrm{C}$ but maximum average power and corresponding maximum energy yield is obtained at higher average cell temperature greater than $51^{\circ} \mathrm{C}$. Voltage variations are more significant compared to current variations and as voltage variations are governed by cell temperature, current variations are governed by irradiance, high and nearly constant $\mathrm{V}_{\mathrm{dc}}$ is obtained only at high cell temperature, the result is that dc power varies in direct proportion to POA only after $\mathrm{V}_{\mathrm{dc}}$ attains nearly high constant value. Further, higher the cell temperature, higher is the average dc voltage and higher is the corresponding energy yield even if POA is comparatively lower signifying the defining positive role of cell temperature in contrast to literature and research papers. The analysis of real field data of Western Rajasthan shows that high cell temperature is the essential requirement and the governing factor in high energy yield bringing forward for the first time ever that cell temperature plays defining positive role on $\mathrm{dc}$ power and correspondingly energy yield. As further work simultaneous effect of cell temperature and irradiance on different technological parameters including solar cell conversion efficiency and energy yield needs to be done for large number of days, for various locations of the world and for different types of solar cells.

\section{ACKNOWLEDGMENT}

The authors would like to acknowledge the support of Shri J. K. Borgohain, Executive Director, Rajasthan Project. Oil India Lmt., Jodhpur, Shri D. C. Gogoi, Head, Technical Service, Oil India Lmt, Jodhpur; Shri Rajesh Kundoo, Incharge, PV Power Plant at Ramgarh, Jaisalmer in conducting this study.

\section{REFERENCES}

[1] Masters, G. M. "Renewable and efficient electric power systems". Wiley Interscience. 2004.

[2] Mayfield, R. Photovoltaic design and installation for dummies. Wiley Publishing Inc. 2010

[3] Dupre. O. Vaillon, R. Green, M.A. "Thermal Behavior of Photovoltaic Devices" Springer International Publishing AG 2017. DOI 10.1007/978-3-319-49457-9_2

[4] Elminir, H. K. Benda, V. Tousek, J. "Effects of solar irradiation conditions and other factors on the outdoor performance of photovoltaic modules". Journal of electrical engineering, Vol. 52, No. 5-6, 2001.

[5] A guide to photovoltaic (PV) system design and installation, a consultant report prepared for California Energy Commission, Energy technology Development Division. June 2001.

[6] Didier T. Richmond, BC. "Review and recommendations for improving the modelling of building integrated photovoltaic systems." Ninth International IBPSA Conference Montréal, Canada. August 15-18, 2005.

[7] Performance of solar power plants in India, Submitted To, Central Electricity Regulatory Commission, New Delhi. 2011.

[8] Amelia, A.R. Irwan, Y.M. Leow, W.Z. Irwanto, M. Safwati,I. Zhafarina, M. " Investigation of the Effect of Temperature on Photovoltaic(PV) Panel Output Performance." International Journal on Advanced Science Engineering Information Technology. Vol. 6 (2016) No. 5. ISSN: 2088-5334 DOI:10.18517/ijaseit.6.5.938.

https://www.researchgate.net/ publication/309600416. 
[9] Mazzeo, D. Matera, N. Bevilacqua, P. Arcuri, N. "Energy and economic analysis of solar photovoltaic plants located at the University of Calabria". International journal of heat and technology. Vol.33 (2015), No.4, pp.41-50. http://dx.doi.org/10.18280 /ijht.330406.

[10] Kozak, T. Maranda, W. Napieralski, A. Mey, G. D. and Vos, A. D. 2009. Influence of Ambient Temperature on the Amount of Electric Energy Produced by Solar Modules. 16th International Conference on Mixed Design of Integrated Circuits and Systems, Poland.

[11] Ciprian, N. Florin, M. Dragos, A. "Annual Energy harvest of LACARP photovoltaic Systems. $6^{\text {th }}$ International conference on modern Power systems MPS 2015, 18-21 May 2015, Cluj -Napoca, Romania.

[12] Mazzeo, D. Matera, N. Bevilacqua, P. Arcuri, N. "Energy and economic analysis of solar photovoltaic plants located at the University of Calabria". International journal of heat and technology. Vol.33 (2015), No.4, pp.41-50. http://dx.doi.org/10.18280/ ijht.330406.

[13] Attari. K. Yaakoubi. A. E. Asselman. A. Comparative Performance Investigations between photovoltaic system for two different cities. $10^{\text {th }}$ International conference inter disciplinary in Engineering, Inter-Eng 2016. $\begin{array}{llll}\text { Procedia Engineering } 181 & \text { (2017) 810-817. }\end{array}$ www.sciencedirect.com.

[14] Mustapha I., Dikwa M. K., Musa B. U. and Abbagana M. Performance evaluation of polycrystalline solar photovoltaic module in weather conditions of Maiduguri, Nigeria. Arid Zone Journal of Engineering, Technology and Environment. August, 2013; Vol. 9, 69-81.

[15] Panagea, I.S. Tsanis, I.K. Koutroulis, A.G. Grillakis, M. G. "Climate Change Impact on Photovoltaic Energy Output: The Case of Greece". Hindawi Publishing Corporation Advances in Meteorology, Volume 2014, Article ID 264506, 11 pages. https://doi.org/10.1155/ $2014 / 264506$.

[16] Babatunde, A. A. Abbasoglu, S. "Evaluation of field data and simulation results of a photovoltaic system in countries with high solar radiation". Turkish Journal of Electrical Engineering \& Computer Sciences. DOI: 10.3906/elk-1402-313. http://journals.tubitak.gov.tr/ elektrik.

[17] Garg, S. JB, Arun and Surana, D. C. 2016. Performance of a Multicrystalline Photovoltaic Module in Critical Climatic Conditions of Western Rajasthan, India. Communications on Applied Electronics (CAE) - ISSN: 2394-4714. Foundation of Computer Science FCS, New York, USA, Volume 5, No.4, June 2016 www.caeaccess.org.

[18] Bhattacharya, T. Chakraborty, A. K. Pal, K. "Effects of Ambient Temperature and Wind Speed on Performance of Monocrystalline Solar Photovoltaic Module in Tripura, India." Hindawi Publishing Corporation. Journal of Solar Energy. Volume 2014, Article ID 817078, 5 pages. http://dx.doi.org/10.1155/2014/817078

[19] Touati, F. Massoud, Hamad, A. J. A. Saeed, S.A. "Effects of Environmental and Climatic Conditions on PV Efficiency in Qatar." International Conference on Renewable Energies and Power Quality (ICREPQ'13) Bilbao (Spain), 20th to 22th March, 2013. Renewable Energy and Power Quality Journal (RE\&PQJ) ISSN 2172-038 X, No.11, March 2013.

[20] Garg, S. and JB, Arun. 2016. High Temperature Effect on Multicrystalline Photovoltaic Module in Western Rajasthan, India. Communications on Applied Electronics (CAE) - ISSN: 2394-4714 Foundation of Computer Science FCS, New York, USA, Volume 4 No.2, January 2016 - www.caeaccess.org.

[21] Garg, S. and JB, Arun. 2017. Evaluating DC Voltage Temperature Coefficient of a Multicrystalline Module in Actual Environmental Conditions of Western Rajasthan, India Communications on Applied Electronics (CAE) ISSN: 2394-4714 Foundation of Computer Science FCS, New York, USA Volume 7 - No. 6, September 2017 www.caeaccess.org.

[22] Garg, S. and JB, Arun. 2018. "Unfolding Extraordinary Positive Effect of High Temperature and High Irradiance on DC Power Output of a Multicrystalline PV Module: A Case Study of Western Rajasthan". Communications on Applied Electronics (CAE) - ISSN: 2394-4714 Foundation of Computer Science FCS, New York, USA Volume 7 - No. 19, August 2018 - www.caeaccess.org. 